\title{
Linking Benthic Macroinvertebrates and Physicochemical Variables for Water Quality Assessment in Lower Dongnai River System, Vietnam
}

\author{
Duc A. Pham, Quoi P. Le, and Nga P. Le
}

\begin{abstract}
The benthic macroinvertebrates living on the bottom channels are one of the most promising of the potential indicators of river health for the Lower Dongnai River System with hydrochemistry playing a supporting role. An evaluation of the interrelationships within this approach deems necessary. This work identified and tested these relationships to improve the method for water quality assessment. Data from over 10,000 $\mathbf{k m}^{2}$ watershed were used as a representative example for Lower Dongnai River and tributaries. The data covered the period March, 2007 to 2010. To implement this evaluation, the analyses were based on accepted MRC method and the studies of scientific group for the biological status assessment. Selected environmental variables were compared with ecological indices, based on benthic macroinvertebrates. Correlation analyses showed significant relationships. The highest scores were found for organic pollution (dissolved oxygen, biological oxygen demand), nutrients (total nitrogen, total phosphorus), and microorganisms (coliform, $E$. coli). Both univariate and multivariate analyses were used to examine the ecological quality of the Lower Dongnai River System using benthic macroinvertebrates seems to be the most sensitive indicator to correlate with physicochemical variables. This demonstrated that it could be applied to describe the water quality in the Lower Dongnai River System.
\end{abstract}

Index Terms-Lower Dongnai River system, benthic macroinvertebrates, physicochemical variables, water quality, correlation analyses.

\section{INTRODUCTION}

The Dongnai River a one of most important river system in Vietnam that originates in the Central Highland of the southern portion of the country and flows through 12 provinces/cities for about $600 \mathrm{~km}$ length and 49,645 $\mathrm{km}^{2}$ area with over 20 millions of people [1]. Especially, development potential of the Lower Dongnai River Basin has prospect of becoming a large economic center that is involved in industries and trade - This region has the biggest economic development in Vietnam. While overal demand in the lower Dongnai River is up, the water resources has been pressured by domestic wastewater, industrial wastewater, municipal and rural wastes, and other human activities. The high

Manuscript received March 13, 2014; revised May 28, 2014

Duc A. Pham is with the Faculty of Environment and Labor Safety, Ton Duc Thang University, Ho Chi Minh City, Vietnam (e-mail: phamanhduc@tdt.edu.vn, anhduc_benthos@yahoo.com).

Quoi P. Le is with the Department of Resource Management, Institute for Environment and Resources, Ho Chi Minh City, Vietnam (e-mail: quoilp@gmail.com).

Nga P. Le is with the Faculty of Biology, University of Sciences, Ho Chi Minh City, Vietnam (e-mail: lephinga1@ @otmail.com). contents of organic pollutants degrade the water quality in receiving waters and threaten the aquatic ecosystems. In addition, the statistics show that the water sources has been, and continued to be, exploited speedily [2].

In order to contribute the water resources management and improve the water quality monitoring for the Lower Dongnai River System, besides the physiochemical measurements, the aquatic organisms for the ecological health monitoring has been applied more and more because of many their advantages. In Vietnam, the aquatic organisms used as indicators of the environmental changes, the benthic macroinvertebrates are good indicators of river health because of particularly useful for biomonitoring. However, up to now, the application of these organisms is rather limited and not verified, especially, the relationships between benthic macroinvertebrates and physicochemical variables for the water quality evaluation [3], [4].

According to this approach, the program "Linking benthic macroinvertebrates and physicochemical variables for water quality assessment in Lower Dongnai River System, Vitenam" will support for researchers and managers in field of ecology, resources and environment, who can applied these studies for the ecological health monitoring in the Lower Dongnai River System. The overall objectives of the research were to: 1) Study on the relationships between benthic macroinvertebrates and physicochemical variables for the water quality assessment in the Lower Dongnai River System; and, 2) Improve the biomonitoring method that serves for the water resources management and the environmental protection in the Lower Dongnai River system.

\section{MATERIALS AND METHOD}

\section{A. Study Sites}

In March 2007 - 2010, the 36 sampling sites in the Lower Dongnai River and tributaries were collected (see Fig. 1).

\section{B. Sampling and Sample Processing}

Sample locations at each site were selected in each of the right and left parts of the river. Five locations were sampled at each of these parts of the river [5]. According to working experiences in studied area, the middle of river need not be sampled because of without change to data collected. Prior to sampling, all the equipment to be used was thoroughly cleaned to remove any material left from the previous sampling site [5], [6].

At each sampling location, a composite of four grabs was 
taken with a Petersen grab sampler, covering a total area of $0.1 \mathrm{~m}^{2}$. If the sampler did not close properly because material such as wood, bamboo, large water-plants, or stones jammed its jaws, its contents were discarded and another grab was taken. The composite sample was washed through a sieve $(0.3 \mathrm{~mm})$ with care taken to be sure that macroinvertebrates did not escape. The contents of the sieve were then placed in jars and fixed with formaldehyde. Samples were sorted in the laboratory, because there was insufficient time at a site. The sample jar was labeled with the site location code, date, position within the river, and replicate number. The sampling location conditions, collector's name were recorded on a field sheet [5], [6].

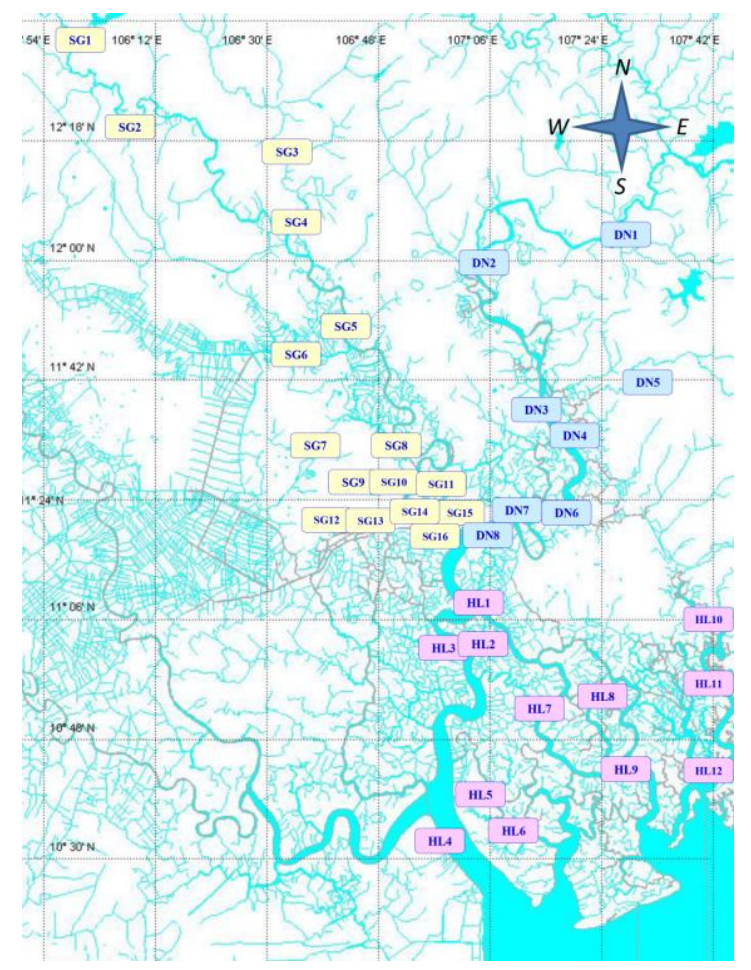

Fig. 1. Map of sampling sites.

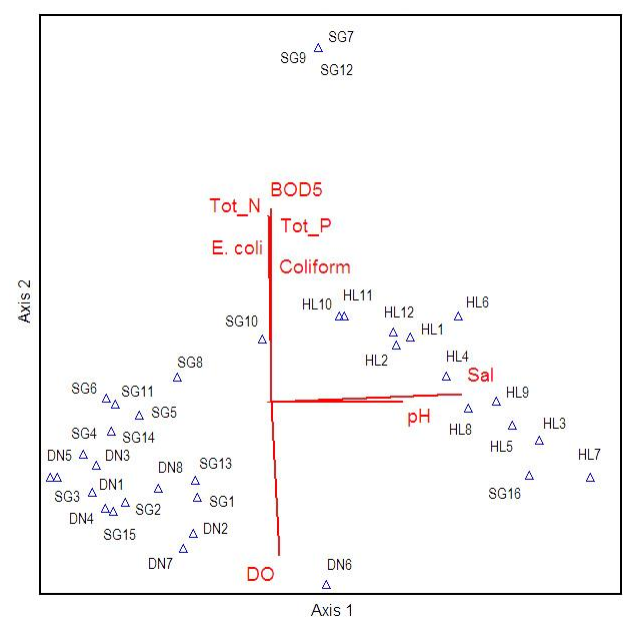

Fig. 2. Ordination graph at 36 sites sampled in March, 2007 - 2010.

All individuals collected were identified and counted under a compound microscope (with magnifications of $40-$ $1200 x)$ or a dissecting microscope $(16-56 x)$. Oligochaeta, Polychaeta, Gastropoda, Bivalvia, Ophiuroidea, and Crustacea were generally identified to species level. Insecta and Insecta larvae were classified only to genus level. The results were recorded on data sheets and specimens are kept at the Ton Duc Thang University, HCMC, Vietnam.

\section{Data Analysis}

For all sites sampled in March 2007 - 2010 the following metrics were calculated i) taxonomic richness (i.e. number of taxa); ii) abundance (i.e. numbers of individuals per site); iii) the Shannon-Wiener Diversity Index [7]; iv) the Simpson Density Index [7]; and, v) the Average Tolerance Score Per Individuals [2]. The five metrics were tested for their potential as indicators of human impact by regressing values for all four years (144 sampling events for 36 sites) against the water quality variables index (temperature, $\mathrm{pH}$, salinity, total suspended solid, dissolve oxygen, biological oxygen demand, total nitrogen, total phosphorus, coliform, and $E$. coli). For each metric examined against these variables, $p$ values and $r^{2}$ values were calculated from regression analyses.

Ordination analysis was performed with the PC-ORD statistical software (version 4.25: MjM Software Design, Geleneden Beach, Oregon, USA) on benthic macroinvertebrate count data transformed as $\log (\operatorname{count}+1)$. The Sorenson (Bray-Curtis) distance measure was used. The stress value lower 20 was accepted. Ordination was done with two-dimensional non-metric multidimensional scaling with varimax rotation. The correlations of the environmental variables with the ordinations were calculated and the strongest correlations were plotted as vectors on the ordination diagrams [8].

\section{RESULTS}

\section{A. General Characteristics of Benthic Macroinvertebrates}

In March 2007 - 2010, 84 taxa of benthic macroinvertebrates were recorded from the 36 sites examined (144 events). The taxa richness of benthic macroinvertebrates in each survey ranged from 68 - 73 taxa (see Table I).

TABLE I: NUMBERS OF TAXA OF MAJOR GROUPS OF BENTHIC MACROINVERTEBRATES IN MARCH, 2007-2010

\begin{tabular}{ccccc}
\hline \hline Classes & $\mathbf{2 0 0 7}$ & $\mathbf{2 0 0 8}$ & $\mathbf{2 0 0 9}$ & $\mathbf{2 0 1 0}$ \\
\hline Polychaeta & 25 & 23 & 25 & 23 \\
Oligochaeta & 2 & 2 & 2 & 3 \\
Gastropoda & 8 & 8 & 7 & 8 \\
Bivalvia & 12 & 11 & 11 & 11 \\
Ophiuroidea & 1 & 1 & 1 & 1 \\
Crustacea & 14 & 14 & 15 & 14 \\
Insecta & 10 & 9 & 12 & 9 \\
\hline Total species & $\mathbf{7 2}$ & $\mathbf{6 8}$ & $\mathbf{7 3}$ & $\mathbf{6 9}$ \\
\hline \hline
\end{tabular}

The polychaets was the most species-rich group and occurred in almost sites. In addition, oligochaets, gastropods, bivalves, crustaceans and insects also occurred widely in the studied areas, while ophiuroids appeared in few sites. Taxon richness at a site ranged widely at the 36 sites sampled in March, 2007 - 2010. Richness ranged from 0 (SG7, SG9, SG12 - canals inside of HCMC) to 17 (HL6 - canal inside of mangrove) taxa.

The number of individuals at sites was highly variable, 
ranging from $0-6,543$ individuals/sample. The density of benthic macroinvertebrates tended to increase too high or to disappear all in near big cities or industrial areas.

\section{B. Bio-Index Analysis}

The values of bio-indices for the water quality assessment for the Lower Dongnai River System were presented in Table II.

TABLE II: BIO-INDICES OF BENTHIC MACROINVERTEBRATES FOR WATER QUALITY ASSESSMENT IN THE LOWER DONGNAI RIVER SYSTEM IN MARCH, 2007-2010

\begin{tabular}{|c|c|c|c|}
\hline Sites & $\mathbf{H}^{\prime}$ & $\mathbf{D}_{\mathrm{S}}$ & ATSPI \\
\hline DN1 & $2.19-2.37$ & $0.63-0.67$ & $50-51$ \\
\hline DN2 & $2.39-2.81$ & $0.69-0.78$ & $43-46$ \\
\hline DN3 & $1.65-1.84$ & $0.50-0.60$ & $50-52$ \\
\hline DN4 & $1.68-2.62$ & $0.49-0.73$ & $48-52$ \\
\hline DN5 & $1.33-1.69$ & $0.42-0.48$ & $52-53$ \\
\hline DN6 & $1.73-2.72$ & $0.47-0.75$ & $49-52$ \\
\hline DN7 & $1.98-2.89$ & $0.61-0.81$ & $48-51$ \\
\hline DN8 & $1.61-2.67$ & $0.46-0.47$ & $52-54$ \\
\hline SG1 & $2.40-3.01$ & $0.70-0.84$ & $42-49$ \\
\hline SG2 & $1.64-2.32$ & $0.47-0.68$ & $49-53$ \\
\hline SG3 & $1.21-1.54$ & $0.40-0.46$ & $52-53$ \\
\hline SG4 & $1.08-1.31$ & $0.33-0.36$ & $53-54$ \\
\hline SG5 & $0.83-1.09$ & $0.21-0.30$ & $54-55$ \\
\hline SG6 & $0.32-0.51$ & $0.08-0.15$ & $54-55$ \\
\hline SG7 & 0 & 0 & 60 \\
\hline SG8 & $0.49-1.18$ & $0.12-0.39$ & $53-55$ \\
\hline SG9 & 0 & 0 & 60 \\
\hline SG10 & $0.32-0.42$ & $0.08-0.12$ & $54-55$ \\
\hline SG11 & $0.41-0.64$ & $0.11-0.16$ & $55-56$ \\
\hline SG12 & 0 & 0 & 60 \\
\hline SG13 & $0.48-0.72$ & $0.15-0.19$ & $54-55$ \\
\hline SG14 & $0.85-1.59$ & $0.22-0.45$ & $53-55$ \\
\hline SG15 & $1.48-2.77$ & $0.44-0.84$ & $49-53$ \\
\hline SG16 & $2.19-2.55$ & $0.63-0.79$ & $41-44$ \\
\hline HL1 & $1.87-2.71$ & $0.51-0.77$ & $42-44$ \\
\hline HL2 & $1.60-1.84$ & $0.44-0.52$ & $43-47$ \\
\hline HL3 & $2.58-3.12$ & $0.74-0.85$ & $40-42$ \\
\hline HL4 & $2.97-3.25$ & $0.82-0.85$ & $42-44$ \\
\hline HL5 & $2.15-2.57$ & $0.60-0.73$ & $40-41$ \\
\hline HL6 & $3.11-3.33$ & $0.80-0.86$ & $36-37$ \\
\hline HL7 & $2.84-3.08$ & $0.76-0.82$ & $40-41$ \\
\hline HL8 & $3.08-3.27$ & $0.81-0.86$ & $38-40$ \\
\hline HL9 & $2.67-3.29$ & $0.81-0.86$ & $38-42$ \\
\hline HL10 & $0-1.10$ & $0-0.38$ & $52-60$ \\
\hline HL11 & $1.26-1.68$ & $0.36-0.49$ & $51-52$ \\
\hline HL12 & $2.03-2.77$ & $0.60-0.75$ & $47-49$ \\
\hline
\end{tabular}

Notes: H' (Shannon-Wiener Diversity Index); Ds (Simpson Dominance Index); ATSPI (Average Tolerance Score Per Individuals).

\section{Relationships of Benthic Macroinvertebrates and Physicochemical Variables}

A two-dimensional ordination of the 36 sites in March 2007 - 2010 (see Fig. 2) had low stress values of benthic macroinvertebrates of 2.61 , indicating that the ordination was good representation of the similarities among the sites.

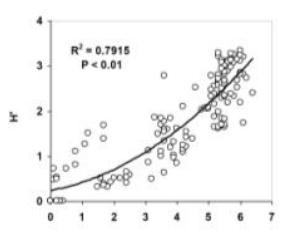

Do (mol)

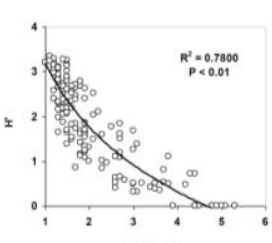

T $N(\operatorname{mgl}$

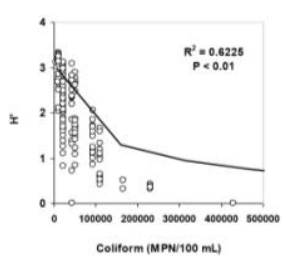

(a)
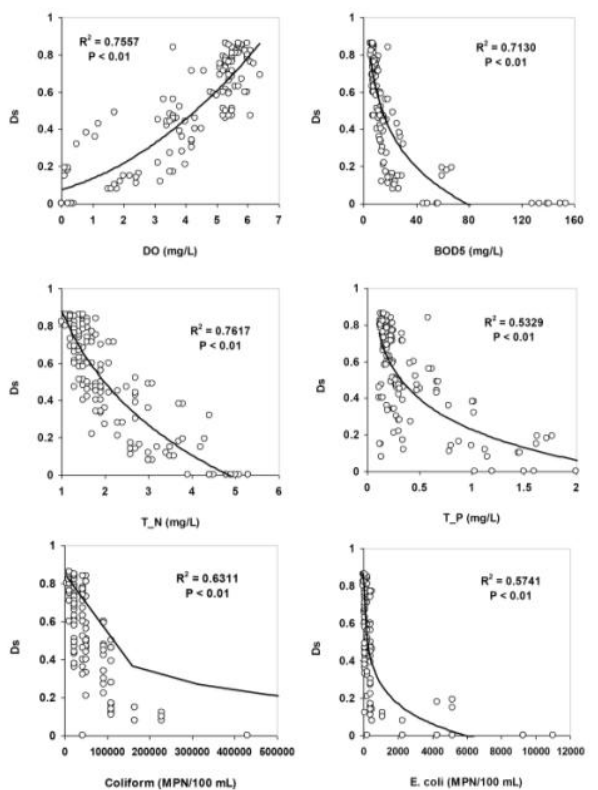

(b)
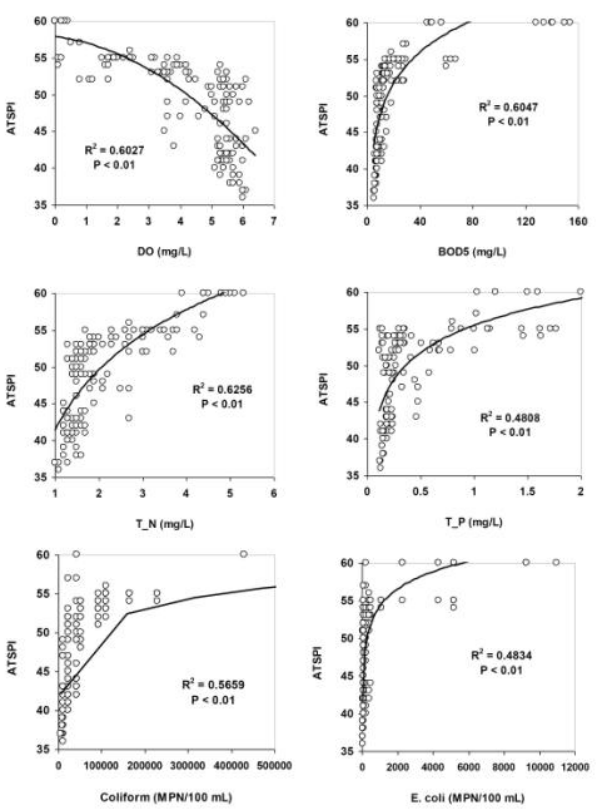

(c)

Fig. 3. Relationships between the metrics of H' (a), DS (b), and ATSPI (c) with the water quality variables for sites sampled in March, 2007 - 2010. 
Salinity, dissolved oxygen, biological oxygen demand, total nitrogen, total phosphorus, and $E$. coli were the environmental variables most strongly associated with this ordination. Meanwhile, temperature and total suspended solid were physicochemical ones unassociated.

Moreover, the metrics of $\mathrm{H}^{\prime}, \mathrm{D}_{\mathrm{S}}$, and ATSPI had significant and strong relationships with the water quality variables of dissolved oxygen, biological oxygen demand, total nitrogen, total phosphorus, coliform, and E. coli $\left(R^{2}=\right.$ $0.4808-0.7915 ; P<0.01$ ) (see Fig. 3a, 3b, and 3c).

The bio-indices did not have a statistically significant relationship with the water quality index $\left(R^{2}=0.0193-\right.$ 0.0777; $P>0.05$ ) (Fig. 4).
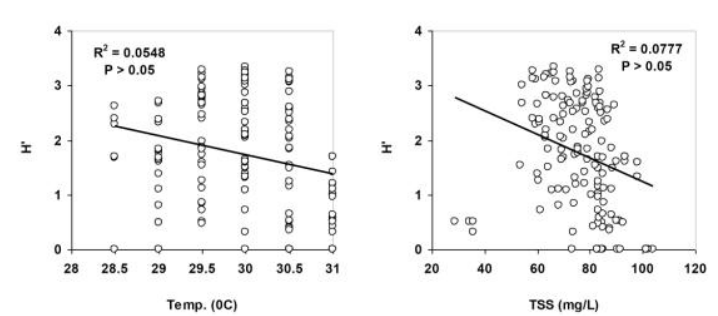

(a)
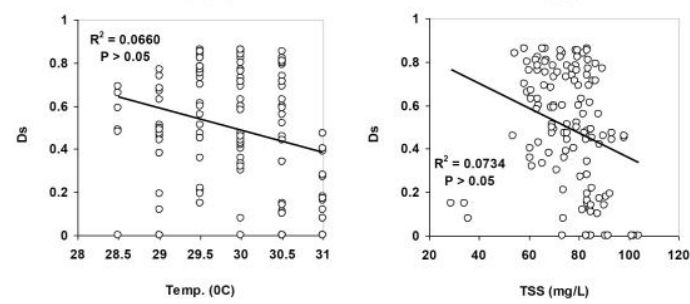

(b)

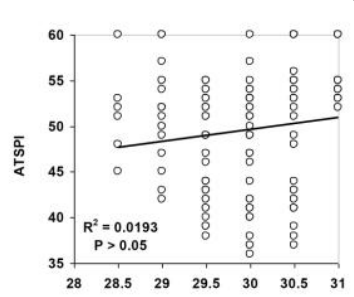

Temp. (OC)

Fig. 4. Relationships between the metrics of H' (a), DS (b), and ATSPI (c) with temperature and TSS for sites sampled in March, 2007 - 2010.

\section{DISCUSSION}

\section{A. General Characteristics of Benthic Macroinvertebrates}

Because of the even and flat terrain with very low slop, the tides from South China Sea came up to near the Dau Tieng Dam - Saigon River and the Songbe River Mouth - Dongnai River [9], [10], and these records were expressed clearly through the appearances of marine and estuaries species such as families Nephthydidae, Nereidae, Sabellidae (Polychaeta) and families Corophiidae, Anthuridae, Corallanidae, Alpheidae (Crustacea). And, all species benthic macroinvertebrate collected in the Dongnai Estuaries were characterized for the brackish water.

The species indicated for rich nutrient and organic pollution occurred in near urban and industrial areas sites with high frequency, including the species of Sedentaria Polychaeta, Tubificidae (Oligochaeta), and Chironomidae
(Diptera). While, the species of Nereidae (Errantia Polychaeta); Gomphidae (Odonata); Rhyacophilidae, Ecnomidae (Trichoptera) were sensitive species with impacts of environmental pollution.

The human activities have influenced strongly on the taxa richness and abundance of benthic macroinvertebrate. The highest taxa richness was recorded in the sites far from industrial parks, crowded citizen areas, big cities (HL6, HL8 and HL9), while the sites near urban HCMC or industrial areas (the section of Saigon River from SG3 to SG14, and the Vedan Port, the Phu My Port) had the low taxa richness because of the more human activities. Especially, there was not any animal that was collected in the three sites of SG7, SG9 and SG12 because of too heavy pollution.

The changes of abundance and dominant species at 36 sites expressed clearly the environmental characteristics of the Lower Dongnai River System and the number of individuals tended to increase in urban and industrial sites, where more organic pollution. The dominant species composition had the high similarities among the site groups. Limnoperna siamenis characterized for the little pollution water was the dominant species in the site DN1, DN2, SG1 and SG2. The species of pollychaets and crustacean were dominant in the estuary sites. In the sites near big towns or industrial areas, the dominant species were Tubificidae and Chironomidae.

\section{B. Bio-Index Analysis}

Generally, the bio-index values of benthic macroinvertebrates had the homogenous changes in the completely studied area. The values tended to decrease in the urban and industrial sites with high turbidity. The results were suitable for the analysis of benthic macroinvertebrates communities.

The bio-index analysis proved that the biodiversity and stability of benthic macroinvertebrates communities tended to decrease in urban and industrial areas; this expressed the worsening water quality situation in the Lower Dongnai River System.

\section{Relationships of Benthic Macroinvertebrates and Physicochemical Variables}

In the ordination analysis of 36 sites sampled in 2007 2010, Axis 1 was mainly associated with $\mathrm{pH}$ and salinity. It tended to separate the upper sites (SG and DN) from the estuaries water sites (HL). Mattson reported that the benthic macroinvertebrates were already dominated by estuarine taxa with a fairly broad salinity tolerance. The salinity increases would affect sensitive taxa, such as aquatic insects, which decline with increasing salinity [11]. While Axis 2 was mainly associated with dissolved oxygen, biological oxygen demand, total nitrogen, total phosphorus, coliform, and $E$. coli. It tended to separate the organic pollution sites (SG6, SG7, SG8, SG9, SG10, SG11, SG12, SG13, HL10, and HL11) from the cleaner sites (SG1, SG2, SG16, DN1, DN2, DN6, HL3, HL4, HL5, HL6, HL7, HL8, HL9, and HL12). Edokpavi indicated the low dissolved oxygen and high biological oxygen demand due to human and domestic wastes discharged, it appeared to be responsible for the structure of the benthic macrofauna community of Ogbe creek. Chironomidae and Naididae as recorded in this area dominated the benthic macrofauna community of Ogbe creek 
[12], as observed for the lower Dongnai River. Furthermore, tubificid worms, thiarid snails, corbiculid clams (upper sites), and Sedentaria species (estuaries) have been recorded to respond organic pollution by increasing in abundance in polluted water bodies. These species appeared and replaced the sensitive taxa such as Ephemeroptera, Pleoptera và Trichoptera (uppers sites), and Errantia species and crustaceans (estuaries).

The regression relationship of the water quality variables with all metrics tended to separate the more turbid sites (HL1, HL2, HL10, HL11 and HL12) with higher richness and values of the diversity and dominance indices from the more stable sites (HL4, HL5, HL6, HL8 and HL9) with lower values of these metrics.

In brief, the ordination and correlation analysis indicated the strong relationship of aquatic communities and environmental variables. Besides, it expressed the groups of sampling sites that supported for the water quality classification and the aquatic ecology zonation by aquatic organisms.

\section{CONCLUSION}

With the purposes of studies on an effective assessment method for scientists in the biomonitoirng, the relationships between benthic macroinvertebrates and physicochemical variables for the water quality evaluation were established. It was a useful method to evaluate and zoning the water quality because of the clear, detail, easily understandable, trustable results.

Additionally, the benthic macroinvertebrate communities and the water quality of the Lower Dongnai River System were presented. The studied results could be applied widely for the ecological health monitoring in the lower Dongnai River and tributaries.

\section{ACKNOWLEDGMENT}

The authors thank Prof. Le Vinh Danh, Rector of Ton Duc Thang University, Vietnam, for his support and encouragement. We sincerely acknowledge Prof. Dao Thanh Son, Institute for Environment and Resources, Vietnam for providing specific papers; and, Prof. Pham Van Mien, Institute of Environmental Science and Development, Vietnam caring for the environmental measurements.

\section{REFERENCES}

[1] V. H. Nguyen, "Overview of water resources in Dongnai River Basin," presented at the Workshop on River Protection, Vietnam River Network, Dongnai, June 6-7, 2009.

[2] A. D. Pham, "Study on the water quality assessment using benthic macroinvertebrate for the lower Dongnai River Biomonitoring," $\mathrm{Ph} . \mathrm{D}$. thesis, Institute for Environment and Resources, Vietnam National University, HCMC, Vietnam, 2014

[3] A. D. Pham, P. Q. Le, and P. N. Le, "Study on the water quality assessment using benthic macroinvertebrates for the Lower Dongnai River Biomonitoring," in Proc. 1st Environment Asia International Conference on Energy, Environment and Climate Change, Thai Society of Higher Education Institute on Environment, Bangkok, 2011, pp. 1026-1041.

[4] P. N. Le, P. Q. Le, and A. D. Pham, "Study on ranking of bio-indices using benthic macroinvertebrates for Lower Dongnai River System, Vietnam," Journal Environmental Science and Engineering, vol. 4, no. 2, pp. 196-205, April 2012.
[5] A. D. Pham, "Biomonitoring of the lower mekong river river and selected tributaries - Benthic macroinvertebrates," MRC Technical Paper, vol. 13, pp. 41-50, December 2006.

[6] A. D. Pham and N. Sangpradub, "Benthic macroinvertebrates," Biomonitoring Methods for the Lower Mekong Basin, MRC, Vientiane, 2010, ch. 8, pp. 49-54.

[7] C. J. Krecbs, Ecological Methodology, Harper Collins Publishers, New York, 1989

[8] B. MacCune, J. B. Grace, and D. L. Urban, "Analysis of ecological communities," Glenedon Beach, Oregon, 2002.

[9] V. M. Pham and T. Le, "Study on Bio-indicators for water bodies in HoChiMinh City," Research Project, HCMC Department of Science and Technology, HCMC, 2004.

[10] A. D. Pham, T. M. L. Nguyen, V. M. Pham, and T. S. Dao, "Aquatic flora and fauna monitoring in Dongnai River System 2006 - 2011," Research Project, Institute of Meteorology, Hydrology and Environment, HCMC, 2012.

[11] R. A. Mattson, "Benthic Macroinvertebrate," St. Johns River Water Management District Palatka, Florida, 2011, ch. 11, pp. 1-105.

[12] C. A. Edokpayi, A. O. Olowoporoku, and R. E. Uwadiae, "The Hydrochemistry and Macrobenthic Fauna characteristics of an urban draining creek," Journal of Biodiversity and Conservation, vol. 2, no. 8, pp. 196-203, August 2010.

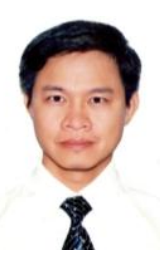

Duc A. Pham is a lecturer of Faculty of Environment and Labor Safety, Ton Duc Thang University (TDTU), Ho Chi Minh City, Vietnam.

He completed his master and $\mathrm{PhD}$ degrees at Institute for Environment and Natural Resources, Vietnam National University at Ho Chi Minh City where his studies focused on methods of the water quality assessment using benthic macroinvertebrates for river health indicators. Pham's research interests relate to the ecological baseline studies also.

Additionally, he spent 5 years to work as a national expert for the Biomonitoring of the Lower Mekong River and selected tributaries of MRC from 2004 - 2008. Pham's laboratory is developing the environmental indication of rapid assessment for water quality and health based on local communities.

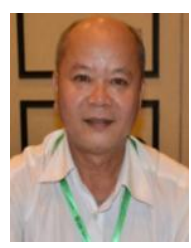

Quoi P. Le is a principal researcher of Institute for Environment and Natural Resources (IER) of Vietnam National University at Ho Chi Minh City, Vietnam, and he also is visiting lecturer of other Universities at Ho Chi Minh City.

He studied on agronomy at Can Tho University. After graduating, he spent 8 years to work as soil scientist of Vietnam - Holland Programme (VH 10), and spent 3 years for project of SARECT conducting in the Mekong Delta. Through the researches of wetlands, he got Belgian Government Scholarship to study in Belgium where he received his MSc in soil science in 1995 at Ghent University and then PhD in 2006.

In addition to teaching, Dr. Quoi has worked in the field of wetland resources in the Mekong River Basin: He joined with Mekong Wetlands Biodiversity Programme from 2004 - 2006, and then part-time member of WWF-Mekong Greater Project from 2008 - 2011 and member of National Working Group of IUCN-Mekong Water Dialogue since 2011. Dr. Quoi has been a national expert of the Peatland Forests Project in Southeast Asia since 2006. He recently collaborated on wetlands/peatlands with the Global Environment Center (GEC) located in Kuala Lumpur and NGOs to organize wetlands assessment in some ASEAN Countries.

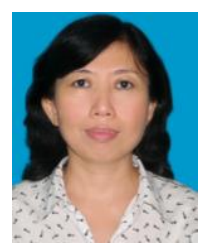

Nga P. Le is an associate professor of biology at University of Science, Vietnam National University at Ho Chi Minh City.

She got her bachelor degree in chemistry in 1986 in Hanoi University and got work in Environmental Microbiology after that in Institute of Biotechnology, VAST, Hanoi, Vietnam. She then completed her master and $\mathrm{PhD}$ degree in bioscience, Faculty of Science at Osaka University in 2001 and spent her postdoctoral work in Molecular Biochemistry in University of Virginia, USA.

In 2004 she moved to the Institute for Environmental and Resource, Vietnam National University at Ho Chi Minh City, to work in environmental biotechnology and ecotoxicolgy. She has been working at the Department of Biochemistry in University of Science since 2008, and hers interests lie at the intersection of environmental biochemistry, metagenomics and environmental biomonitoring. 